\title{
INVESTIGATING THE ROLE OF DOMESTIC TOURISM ON LOCAL ECONOMIC DEVELOPMENT (CASE STUDY: ISFAHAN LENJAN CITY)
}

\author{
Ali Olyaee \\ Department of urban planning, Isfahan(khorasgan) Branch, Islamic Azad University, Isfahan, Iran \\ ali.olyaee@gmail.com \\ Ali Mokhtari \\ MSc student at urban planning, Amin Institute of Higher Education, foladshahr, Iran \\ alimokhtari541@yahoo.com \\ Narges Khademi \\ MSc student at urbanization, Amin Institute of Higher Education, foladshahr, Iran \\ nargeskhademi72@gmail.com
}

\begin{abstract}
Tourism industry development for Lenjan city which face with difficulties such as high unemployment rate, energy source constraints and also single-product economy, have high importance. with regards to the extent of domestic tourism functionality in city, can in addition to positive economic effects of tourism in city's growth and activeness, leading to provide cultural-social development, in spatialskeletal dimensions and political dimensions (security creating, state and private institutes existence in region,...), that needs to be planned in the of objective of sustainable development until economic development achieved in city as a real sense. This research has done on descriptive-analytical method and gathering first-hand information, which using SWOT model, it investigate strength, weakness points, opportunities and threats which finally which leading to introducing solutions like justly services and facilities distribution, holding festivals (cultural, artistic and sport), developing transportation infrastructure quality, state's support and encourage from private sector investments, using mass media and social networks in introducing tourism attractions and city's tourism universe plan compilation in order to regional development that all can provide economic development and growth in Lenjan city level area.
\end{abstract}

Keywords: Domestic tourism, Local economic development, Lenjan city, Stability

\section{INTRODUCTION}

Today, tourism industry changes to one the greatest active industry in the world (Kargar, 1389). And according to opinion of world tourism organization-related to united nation-is the greatest active industry in world, and consider as the greatest economic activity (bigger (greater) than defense industry, industrial production, oil and agriculture,...) (Donald et al, 1386), Also this industry is the third job's and capital's generating industry after oil and automobile manufacturing industry. For this reason in recent decades, most of the states, economic officials, authorities pay attention to developing this industry with more sensitive and they tried to brings more share of this world market's industry for it's society (Mohammad Pour Zarandi and Tabbatabbie, 1389). According to world tourism organization report, Iran has a 10 rank of historical and ancient attractions and rank 5 of natural attractions. However, in the terms of exploitation of these sources hasn't been in suitable (desirable) place, while despite its superior rank in tourist attractions, Iran's share from world tourism income doesn't reach to one percent. Iran's country is in most attractive world's countries group in terms of historical and natural usability (capacities), Bio diversity and complete 4 season existence and unique natural attractions near Iranian culture indicates high tourism development capacity in Iran. These factors can lead planners and policy makers toward planning with relying on territorial powers (abilities), domestic tourism can pose as an important part in income-born (making) and economic prosperity in national level. On the other hand, domestic tourism as a strategy for economic plans in 
this research, we investigate the relationship between domestic tourism in order to fulfilling strength economic. Given the sense of urgency space management in macro level rather than program's implementation and monitoring, there are different tools for fulfilling with focus on tourism via SWOT (methods) that used by planners: according to this method, first local economic development's strength, weakness points, opportunities and threats are recognized and after realistic recognition from current situation, we try to introduce solutions and recommendations in order to resolve economic development barriers in local level.

So the main questions of this research is that:

What are the strength, weakness points, opportunities and threats to economic development in Lenjan city? What are the strategies for local economic development with tourism approach?

\section{DATA ANALYSIS METHOD}

Strategic analysis method (SWOT), organization's external and internal environments, performance control and evaluation, processes efficiency and effectiveness are investigated. In facts, strategic management investigates the interaction's style of organization's internal and external environment via suitable (ideal) strategy compilation (Mirmiran, 1384).

SWOT considered organization's external environment as to discover opportunities and threats and consider internal environment as to understand strength, weaknesses points.

Strategic analysis includes measures and plans that. It's result is to maximize the opportunities and strengths and to minimize weaknesses and threats. This method is the most important tools as to adopt organization's strength and weakness points with a head opportunities and threats. This model introduced systematic analysis as to recognize factors in selecting ideal strategy external opportunities and threats are compared with internal strengths and weaknesses and adaptation pattern of internal and external situation are recognized that includes (contains) adopting one of the following patterns:

1) (S) internal strength points, 2) (W) internal weakness point, 3) (O) external opportunity, 4) (T) external threat.

Table 1: SWOT Matrix

\begin{tabular}{|c|c|c}
\hline Threats & Opportunities & \\
\hline ST strategy & SO strategy & Strength points \\
\hline WT strategy & WO strategy & Weakness points \\
\hline
\end{tabular}

SWOT Matrix can have same another form which are not practically difference.

S-O: are strategies that seeking to use opportunities and well-matched with organization's abilities.

W-O: usually on weakness in order to use opportunities.

S-T: identify ways that firm (companies) can use to reduce the risk of threats.

W-T: is complete (perfect) defense strategy that prevent firm's (company's) from hurt due to it's weaknesses from external environment threats.

\section{THEORETICAL FRAMEWORK}

\section{THE LOCAL ECONOMY}

The late 21 the century will register with power increasing focus and perfect multinational company's domination on world economic management, that easily can penetrate in all of the people's life dimensions and leading to life-style changing with regards to and supported group it's long time 
interest and demands (needs). Features of this period, surely (certainly) collapse of self-help and selfreliance systems in world local societies and as result the advent of country's widespread economic dependence on world business even for its most basic needs like food, and as result country's political vulnerability on world economic masters hand. Local economic development authorities, recognize human greed as a main factor for creating economic disorders and current environmental damage (Norenburg, Hodge, 2010). This wide villages (rural) collapse as a main country's agriculture self-help and self-reliance, indicate this fact that great (major) companies which always seek to open markets for its art crafts and more access to primary sources, puts local societies as its fundamental conflicts.

This is big statements that have strategic importance for policy making and planning in independent countries. There is another reason for authenticity of this interpretation.

So, therefor, local economic can be said that are societies success in achieving to universe local development, means that synchronized development to environment, economic, society, technology and culture. In practice, these local societies resist against world economic fluctuations and crisis and provide significant experiences and patterns for citizens and policy-makers in other world countries.

\section{THE OBLIGATIONS OF PAYING ATTENTION TO LOCAL ECONOMIC}

There is no doubt that today's Iran situation is not such that describe it on a normal and usual facts frames. So administration including country's economic management needs special arraignments. On the other hand human sources (that contains cultures and local custom existence, handicrafts, local foods, historic building) and natural sources (deserts, natural wildernesses, morphological mistake, species,...) as a potential country capital can allocate each special tourism centers to itself at inside and outside of country. And are suitable area for using these sources in order to region's economic prosperity and finally region's developing.

\section{DOMESTIC TOURISM}

According to world tourism organization definitions "tourism assign to trip action as to recreation and outing and providing necessary services for this acts, and tourism assign to a person, who keep a 80 $\mathrm{km}$ distance away from home with the aim of recreation and outing" (Bemaniyan and Mahmoud Najhrad, 1388).

Domestic tourism are the valuable sources that allow organization to do its activities and functions in the best manner and with low fee from competitions, In one country, tourism industry count as a competitive advantages that consider as a income source for one country, especially if tourism advantages are rare, inimitable and attractive (Taybi and others, 1387:41).

\section{MUTUAL RELATIONSHIP OF DOMESTIC TOURISM AND ECONOMY}

As already noted, tourism industry have a significant effects on urban and regional economic from different dimensions. The first reason of tourism industry development in the most countries is using economic interest. On the other hand, economic growth has effects on domestic tourism development (Taybi et al, 1387).

Therefore, there is a direct relationship between degree of development of host region and tourism industry effective ness rate on economic growth. Economic growth, with developing tourism infrastructures and facilities including routes transportation development, ICT development, electronic money development, residential places development, restaurants and hotels, public health development and also recreation facilities and welfare tasks development caused developing tourism industry. In the other words, cost allocation matter from tourisms side related to facilities range and attractions diversity, this matter develop economic activities volume related to tourism industry in host region and have direct effect on of this industry in country's economic growth.

\section{THE ROLE OF TOURISM IN ECONOMIC DEVELOPMENT}

While the economic issue has been casted for economic planners. The development matter (subject) can be reach to desirable result that all of the economic sectors moved align and parallel toward 
defined target. The aim is coping with economic challenges and interrupting dependency to necessary products and services of tourism is the arena of actualizing the ideals, cultures and beliefs and different potential abilities. Tourism has a feature that can consider as economic development propulsion in all of the countries (Kargar, 1386). Tourism industry development for countries that face with difficulties like high unemployment rate, energy sources constraint and also single-product economic, have high importance (Kargar, 1386). Economic experts believe that if a country can use potentials and move this industry's wheel, we will witness of tremendous prosperity in economic level. The effects of this industry are searchable and important.

Some of them include:

Employment in many areas, activeness of retail market, transportation system activation, investment increasing, local, native, industrial products, increasing (handicrafts and cultural products), private sector investment rate increasing (Hotel-building and other related services) and many others.

\section{INTRODUCING STUDIED AREA}

Lenjan city is located in geographical position of 50 minutes and at least $56^{\circ}$ degrees and 51 minutes and maximum $28^{\circ}$ degrees of east along and at least 32 minutes and 11 degree and maximum 32 minutes and 31 degrees of north width. This city formed along Zayandeh Rood River on the area of Lenjan plain. The city area is $1172 \mathrm{~km}$ and located in $35 \mathrm{~km}$ of Isfahan southwest. The relative height from sea level is $2270 \mathrm{~m}$ and have variable climate (weather) which are always influenced by the central semi-arid zone and semi-humid of ChaharMahal Bakhtiyari. City's political division has two parts: the central and 8 city.

Table 1: Strength and weakness points of studied area/

Source existence finding

\begin{tabular}{|c|c|c|}
\hline Indexes & Strength points & Weakness points \\
\hline Economic & $\begin{array}{l}\text { 1. industrial industry existence } \\
\text { 2. Abundant young labor force } \\
\text { 3. workshop existence } \\
\text { 4. agriculture existence } \\
\text { 5. Income-making from tourism } \\
\text { 6. sport's potential existence } \\
\text { 7. facilities and healthcare service existence }\end{array}$ & $\begin{array}{l}\text { 1. light existence of private sector's investors } \\
\text { 2. lack of governmental financial support } \\
\text { justly agriculture section } \\
\text { 3. lack of water for agriculture and industry } \\
\text { section } \\
\text { 4. lack of fair distribution of services in city } \\
\text { level } \\
\text { 5. lack of region's competitiveness with } \\
\text { neighborhood regions } \\
\text { 6. unbalanced distribution of healthcare } \\
\text { service } \\
\text { 7. low quality of healthcare service } \\
\text { 8. manpower unemployed } \\
\text { 9. hidden employment existence } \\
\text { 10. low service productivity } \\
\text { 11. agriculture productivity depression } \\
\text { 12. livestock depression } \\
\text { 13. productions and arable lands decrease } \\
\text { 14. Gardening section depression }\end{array}$ \\
\hline Social & $\begin{array}{l}\text { 1. Interethnic social capital existence } \\
\text { 2. a lot of youth } \\
\text { 3. Residents participate in serving the tourists } \\
\text { 4. kind and hospitable people existence } \\
\text { 5. Awareness increasing toward another } \\
\text { region's people } \\
\text { 6. participate in keeping historical capitals } \\
\text { 7. security existence }\end{array}$ & $\begin{array}{l}\text { 1. lack of awareness of tourist's entry benefits } \\
\text { 2. tourists carelessness toward natural } \\
\text { environment right } \\
\text { 3. carelessness to women and Elderly right } \\
\text { 4. lack of local social service } \\
\text { 5. lack of training in the event of hospitable } \\
\text { 6. The lack of tourism research center } \\
\text { existence }\end{array}$ \\
\hline Cultural & 1. different Ethnic (nationality) existence & 1. invasive culture entry \\
\hline
\end{tabular}




\begin{tabular}{|c|c|c|}
\hline & $\begin{array}{l}\text { 2. Having local traditions } \\
\text { 3. variety in local and special foods } \\
\text { 4. Lenjani Dialect } \\
\text { 5. local Handicrafts } \\
\text { 6. religious places existence }\end{array}$ & $\begin{array}{l}\text { 2. carelessness to offering cultural and } \\
\text { Mythical symbols } \\
\text { 3. lack of support in source allocating for } \\
\text { brand making } \\
\text { 4. lack tourism culture promotion }\end{array}$ \\
\hline $\begin{array}{l}\text { Skeletal- } \\
\text { Spatial }\end{array}$ & $\begin{array}{l}\text { 1. natural places existence } \\
\text { 2. historical monuments existence } \\
\text { 3. the existence of structures with local } \\
\text { architecture style } \\
\text { 4. Zayandehrood river existence } \\
\text { 5. Lush (green) forests existence } \\
\text { 6.the existence of suitable transportation } \\
\text { infrastructure } \\
\text { 7.the existence of terminal with regional } \\
\text { board } \\
\text { 8. the existence of four climate in the city } \\
\text { 9. beautiful view existence } \\
\text { 10. Health care services existence }\end{array}$ & $\begin{array}{l}\text { 1. lack of Guest house and residential places } \\
\text { 2. transportation's weariness } \\
\text { 3. lack of variety in transportation's equipment } \\
\text { (instruments) } \\
\text { 4. lack of between-way's services } \\
\text { 5. natural region's destroy } \\
\text { 6. air pollution } \\
\text { 7.the lack of centers for guiding passengers } \\
\text { 8. the lack of environment plan }\end{array}$ \\
\hline Political & $\begin{array}{l}\text { 1. security establishment } \\
\text { 2. investment in economical sections } \\
\text { 3. authorities note toward tourism section's } \\
\text { importance } \\
\text { 4. state investment in tourism section } \\
\text { 5. Budget determination for services section }\end{array}$ & $\begin{array}{l}\text { 6. the lack of notification by national and } \\
\text { local media } \\
\text { 7. light existence of NGO one notification, } \\
\text { informing, promotion and introduction } \\
\text { 8. the lack of rules for supporting tourism } \\
\text { section } \\
\text { 9. lack of universal tourism plan for city } \\
\text { 10. lack of budget for tourism section } \\
\text { 11. lack of tourism notification base in city }\end{array}$ \\
\hline
\end{tabular}

Table 2: Opportunities and threats of studied area/ source: research findings

\begin{tabular}{|c|c|c|}
\hline Indexes & Opportunities & Threats \\
\hline Economic & $\begin{array}{l}\text { 1. Economic prosperity with regards to } \\
\text { tourism development } \\
\text { 2. Income making from sport tourism } \\
\text { 3. making suitable (desirable) market for } \\
\text { tourism } \\
\text { 4. tourism firms existence with regional } \\
\text { board }\end{array}$ & $\begin{array}{l}\text { 1. retardation in tourism growth } \\
\text { 2. lack of competitiveness } \\
\text { 3. Drought and famine crisis as result } \\
\text { of agriculture destruction } \\
\text { 4. economic downturn (depression) } \\
\text { 5. unwillingness to private sector's } \\
\text { investment in tourism section } \\
\text { 6. host's risk reduction from } \\
\text { investment }\end{array}$ \\
\hline Social & $\begin{array}{c}\text { 1. using social networks for introducing } \\
\text { tourism regions } \\
\text { 2. human force nurturing } \\
\text { 3. developing educational tourism } \\
\text { centers } \\
\text { 4. creating ideal (suitable) place for } \\
\text { holding tourism events } \\
\end{array}$ & $\begin{array}{l}\text { 1. lack of using region tourism } \\
\text { power due to the lack of knowledge } \\
\text { 2. Dissatisfaction with tourists from } \\
\text { residence } \\
\text { 3. reduce the desire for re-election } \\
\text { for tourism } \\
\text { 4. lack of skilled manpower }\end{array}$ \\
\hline Cultural & $\begin{array}{l}\text { 1. holding artistic-cultural festivals } \\
\text { 2. introducing tourism places } \\
\text { 3. holding religious ceremony } \\
\text { 4. symbolism in the event of introducing } \\
\text { regions (brand-making) } \\
\text { 5. Attract cultural tourism } \\
\text { 6. Delivery special service for } \\
\text { recreational tourism }\end{array}$ & $\begin{array}{l}\text { 1. Away from the local culture } \\
\text { 2. the possibility of creating sense of } \\
\text { place belonging in host } \\
\text { 3. the disappearance of native culture } \\
\text { 4. Reducing cultural tourism entry }\end{array}$ \\
\hline
\end{tabular}




\begin{tabular}{|c|c|c|}
\hline $\begin{array}{l}\text { Spatial- } \\
\text { Skeletal }\end{array}$ & $\begin{array}{l}\text { 1. the existence of talented regions for } \\
\text { attracting different tourism species } \\
\text { (types) } \\
\text { 2. using historical regions in order to } \\
\text { increasing domestic tourists } \\
\text { 3. residential service developing } \\
\text { 4. increasing recreational facilities } \\
\text { 5. suitable service distribution in order } \\
\text { to increasing access } \\
\text { 6. suitable tourists distribution }\end{array}$ & $\begin{array}{l}\text { 9. changing land use without paying } \\
\text { attention to detailed plan } \\
\text { 10. lack of supervision on } \\
\text { construction } \\
\text { 11. the lack of enough space } \\
\text { 12. dissatisfaction with } \\
\text { transportation services } \\
\text { 13. beautiful view destroy } \\
\text { 14. High coefficient of natural } \\
\text { Hazards } \\
\text { 15. reducing natural resources } \\
\text { 16. increasing energy consumption } \\
\text { 17. changes in region ecology }\end{array}$ \\
\hline Political & $\begin{array}{l}\text { 1. creating institution related to tourism } \\
\text { 2. enforce state politics } \\
\text { 3. fulfilling the wishes of state in the } \\
\text { light of people's need } \\
\text { 4. economic section movement in the } \\
\text { event of macro-politics } \\
\text { 5. creating ideal bed for trust-making } \\
\text { among people and authorities }\end{array}$ & $\begin{array}{l}\text { 1. the lack of tourism prosperity in } \\
\text { the region } \\
\text { 2. reduce the relationship among } \\
\text { authorities and residents } \\
\text { 3. failure to gain the trust of tourists } \\
\text { 4. the lack of knowledge from (of) } \\
\text { tourism power (ability) } \\
\text { 5. unsystematic and irregular tourism } \\
\text { existence and finally frustration }\end{array}$ \\
\hline
\end{tabular}

\begin{tabular}{|c|c|c}
\hline Priority & Strategy & Description \\
\hline $\mathbf{1}$ & WO & $\begin{array}{r}\text { Improving the Quality and quantity of facilities and welfare service } \\
\text { with regards to area position (condition) in nature bed. }\end{array}$ \\
\hline $\mathbf{2}$ & SO & $\begin{array}{r}\text { Benefits from all of the natural and historical potentials, with } \\
\text { regards to environmental powers and capacities }\end{array}$ \\
\hline $\mathbf{3}$ & ST & Preventing from decreasing factors of tourism attractions \\
\hline $\mathbf{4}$ & WT & $\begin{array}{r}\text { Foreign and domestic investors attraction in order to develop area } \\
\text { economic with emphasis on natural attraction }\end{array}$ \\
\hline
\end{tabular}

\section{CONCLUSIONS}

With regards to this matter, that Lenjan city have high tourism potential, that needs to be planned in sustainable development framework. Economic feel more than ever via tool and territorial capacities tourism development in Lenjan city as a strategy in the event of sustainable framework can play an important role in third section of economic means services. With regards to the extent of the functionality (operation) of domestic tourism in city, in addition to positive economic effects of tourism on city's growth and activeness, leading to develop social-cultural dimensions like (social capital and trust developing among Ethnicity, cultural tensions reducing, making bed for developing host's and tourist's social-cultural knowledge), in physical-sketel dimensions (such as historical building repairing and preserving, city development, and attention to natural environment stability, introducing natural regions in order to present region capabilities,...) and finally in political dimensions (security, private and state institutes existence in region and,...), with regards to collected date, it seems that domestic tourism development have a role as a one of the (effective) strategies in economic development. Of course, it should be considered that pre requirement of this opinion (view) is fulfilling domestic tourism infrastructure-are dimensions and resolve political, economic, socialcultural and physical problems and barriers, in this regard (context), proposals in two strategy dimension are to fulfilling-term tourism aim (goal) in region and case goals to resolve barriers and problems and reaching to early returns aims (goals).

\section{THAT THE CASE IS}

1. Strategic suggestion 
1. Study and region tourism features specially domestic tourism in order to awareness from tourism development (like the volume of tourists, paths, different regions, tourist's imagery,...), distribution service facilities style, study barriers and problems in each of the tourism regions.

2. Complete (perfect) tourism plan compilation for each city of Lenjan city with regards to their historical-religious features.

3. Holding cultural weeks and introducing their tourist areas.

4. Expanding performing search conditions and tourism studies in universities and applied research.

5. Expending and developing modern transportation tools, expanding services and using the means of communications.

6. Encourage people and different state and private sectors for macro investment in domestic tourism area.

7. Expanding (development) transportation in terms of quality and transportation system type (kind).

8. Credits allocation in developing area of building infrastructures and ideal facilities for tourist attraction.

9. Create notification bases and introducing city's tourism attractions.

10. Introducing the tourism potential of city's villages via media spaces and advertising brochures.

11. Presenting economic facilities to private sectors for entering to investment areas in domestic tourism area.

12. Creating economic opportunities in rural regions avoiding from (preventing from) presenting personal tastes in domestic tourism area.

\section{SPECIAL OFFERS}

1. Increasing hotels number with high quality.

2. Resolving the weakness on hotel service and restaurant services.

3. Allocate the old (ancient) parts of the historical cities to domestic tourism activities.

4. Developing of recreational camps.

5. Enhance access (travel's time and cost).

6. Service recovery

7. Developing group's tour

8. Developing tourism centers in south coast.

9. Developing natural and rural tourism (ecotourism). 